\title{
ABSTRACTS - ABSTRAKTIT
}

\section{悋}

Ilkka Levä

\section{RAISED BY TV. THE META- CINEMATIC IMAGE OF WORK IN FIGHT CLUB}

The film Fight Club was a cinematic machine, which modelled and produced the affective labor of work in a neoliberal society. The analysis is based on Jonathan Beller's theory of cinematic mode of production. Spectators were calibrated to do the viewing work required of attention economy. As a reward, they attained different modes of entertainment and enjoyment. In the article, Gilles Deleuze's concept of "the image of thought" is reformulated and put to use as the concept of "the image of work".

At the metacinematic level, Fight Club is argued to produce an image of spectatorship as consumerism, as well as a generalized image of work. As a producing machine, Fight Club tries to flee the alienating affects of working life to the "black holes" of marginality. As an attention economy spectacle, it simultaneously enfolds the viewers in the web of global culture industry, transforming the viewer experience in the social field of global societies. The article centers on the question of how Fight Club effected the typical image of work in neoliberal societies.

Keywords: affect, meta-cinema, image of work, attention economy, neoliberalism

\section{TELEVISION KASVATTAMAT. FIGHT CLUBIN METAELO- KUVALLISUUS JA SEN TYÖN KUVA}

Fight Club toimi uusliberalistisen yhteiskuntajärjestelmän työhön liittyvää affektituotantoa mallintavana ja tuottavana elokuvallisena koneena. Analyysi perustuu Jonathan Bellerin elokuvallisen tuotantomuodon teoriaan. Elokuvalla katsojat kalibroitiin tekemään huomiotalouden vaatimaa katsomistyötä. Palkaksi he saivat erilaisia viihtymisen muotoja. Gilles Deleuzen "ajattelun kuva" -käsitteelle rinnasteisena kehitellään "työn kuva" -käsitettä.

Elokuvassa tuotettiin metaelokuvana sekä kuluttamiselle perustuvaa katsojakokemuksen tilaa että yleisempää työn kuvaa. Tuottavana koneena eli metaelokuvana Fight Club koetti paeta työelämän tuottamia vieraannuttavia affekteja marginaalisuuden "mustiin aukkoihin". Huomiotalouden spektaakkelina se kuitenkin kietoi katsojansa globaaliin kulttuuriteollisuuden verkostoon muuttaen katsojakokemusta yhteiskuntien sosiaalisella kentällä. Artikkelissa pohditaan, miten Fight Club vaikutti uusliberalistiselle yhteiskuntajärjestelmälle tyypilliseen työn kuvaan.

Avainsanat: affekti, metaelokuva, työn kuva, huomiotalous, uusliberalismi

\section{Heidi Kosonen}

\section{RITUAL DEATH AND FAMILY TRAGEDY: ON SUICIDE'S DEFINITION AND TABOO IN FOLK HORROR FILM MIDSOMMAR}

Films, especially Anglo-American ones, frequently depict suicide. Their representations reflect cultural understandings of suicide, but also independently influence how selfwilled death is perceived. In this article I study how suicide is depicted in Ari Aster's folk horror film Midsommar (2019). In the film, the protagonist Dani, who is mourning her sister's murder-suicide, travels from the US to a Swedish commune, Hårga, with her boyfriend and his friends. The Hårgan midsummer ritual reveals differences in the two cultures' relationships to death, emotional expression, and family.

One the one hand, I focus on the way the film reflects suicide's nature as a taboo, as something simultaneously hidden and hypervisible. In the diegesis, suicide appears as a silenced trauma, as a source of disenfranchised grief, and as a death the protagonist is not allowed to mourn. Simultaneously the film reflects suicide's instrumentalization and pornification in Anglo-American entertainment.

On the other hand, I focus on questions related to the definition of suicide or self-willed death. The film depicts conflicts between two cultures, where different explanation models of self-willed death are juxtaposed with one another. On display are two types of suicides that can be referred to as "egoistic" and "altruistic" by reference to Durkheim's typology, which takes into account suicide's relationship to society. Yet in Midsommar's diegesis, these deaths appear as psychologized and culturally marginalized "diagnostic" and "cultist" suicides, and thus reflect the power of normative biopower over how self-willed death is understood and made sense of in the west.

Keywords: taboo, death, suicide, folkhorror, biopower

\section{RITUAALIKUOLEMA JA PERHETRAGEDIA: ITSEMURHAN MÄÄRITTELY JA TABULUONTEISUUS KAUHU- ELOKUVASSA MIDSOMMAR - LOPUTON YÖ}

Elokuvissa ja erityisesti angloamerikkalaisissa elokuvissa kuvataan itsemurhaa usein. Niiden representaatiot heijastelevat kulttuurisia käsityksiä itsemurhasta, mutta myös itsenäisesti vaikuttavat käsitysten syntymiseen. Tässä artikkelissa tarkastelen Ari Asterin folk-kauhugenreä edustavaa elokuvaa Midsommar - loputon yö (2019). Elokuvassa sisarensa tekemää murhaitsemurhaa sureva Dani matkustaa Yhdysvalloista Ruotsiin fiktiiviseen Hårga-kommuuniin poikaystävänsä ja tämän ystävien kanssa. Hårgalainen juhannusrituaali paljastaa eroja amerikkalaisen ja hårgalaisen kulttuurin välillä muun muassa kuolemasuhteeseen, tunteiden ilmaisuun ja perheeseen liittyen. 
Keskityn artikkelissa yhtäältä itsemurhaan tai omaehtoiseen kuolemaan tabuluonteisena kuolemana, johon liittyvää samanaikaisen näkymättömyyden ja hypernäkyvyyden dynamiikkaa elokuva mielenkiintoisella tavalla käsittelee. Midsommarin tarinankaaressa itsemurha näyttäytyy vaiettuna traumana ja oikeuttamattomana surun lähteenä, jonka käsittelyä Danin lähipiiri ei tue. Samalla elokuva heijastelee itsemurhan välineellistymistä ja pornoistumista angloamerikkalaisessa viihteessä

Toisaalta keskityn omaehtoisen kuoleman määrittelyn kysymyksiin tarkastelemalla elokuvan esittämää kulttuurista törmäyspistettä, jossa vastakkain asettuvat kahdenlaisten selitysmallien alle asettuvat itsemurhat. Näitä kuolemia voidaan määritellä egoistiseksi ja altruistiseksi viitaten durkheimilaiseen typologiaan, jossa itsemurha esiintyy aina suhteessa yhteiskuntaan. Toisaalta Midsommarin tarinamaailmassa itsemurhat redusoituvat "diagnostisiksi" ja "kultistisiksi" marginalisoiduiksi kuolemiksi ja siten heijastelevat normatiivisen biovallan selitysmallien valtaa itsemurhan määrittelyn kysymyksiin.

Avainsanat: tabu, kuolema, itsemurha, folk-kauhu, biovalta

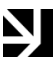

\section{Sini Mononen}

\section{THE MUSIC OF SUSPICION AND THE MONTAGE OF FORGIVENESS: MUSIC AS AN AFFECTIVE IMAGE OF THE COMMUNITY IN THE TELEVISION SERIES KAIKKI SYNNIT}

This article discusses the affective representation of the community in the music of the Nordic noir TV series Kaikki synnit (dir. Mika Ronkainen). The genre of Nordic Noir includes suspicion as a key affect. The article looks at the central theme of Kaikki synnit, forgiveness, as an affective counterpart of suspicion.

The story world of the series is set in the fictional North Ostrobothnian town of Varjakka, where the majority of the population are conservative Laestadians. For Nordic noir, in a genre-specific way, the story of the series arises from a topical sociopolitical issue, which in the TV series Kaikki synnit is gendered violence and sexual harassment. The theoretical background of the analysis of the series is formed by recent affect theory, where affect is understood as a social and cultural phenomenon.

The music in Kaikki synnit TV series draws on affect as a key factor in the viewing experience. In the story world of the series, the affectiveness of the community is represented as bonds and breaks, which is echoed in the music of the series. The series is viewed in light of feminist aesthetics: instead of repeating unambiguous violence, the series tends toward narration where the end point of the story is not revenge but reconciliation with the past.

Keywords: Kaikki synnit, Nordic Noir, music in television series, affect, sexual harassment, feminist aesthetics

\section{EPÄILYKSEN MUSIIKKI JA} ANTEEKSIANNON MONTAASI: MUSIIKKI YHTEISÖN AFFEKTIIVISENA KUVANA TELEVISIOSARJASSA KAIKKI SYNNIT

Artikkeli käsittelee yhteisön affektiivista kuvaa nordic noir -televisiosarjan Kaikki synnit (ohj. Mika Ronkainen) musiikissa. Nordic noirin lajityyppiin kuuluu keskeisenä affektina epäilys. Artikkelissa tarkastellaan sarjan keskeistä teemaa, anteeksiantoa, epäilyksien affektiivisena vastinparina.

Sarjan tarinamaailma sijoittuu fiktiiviseen pohjoispohjanmaalaiseen Varjakan kuntaan, jonka valtaväestö on vanhoillislestadiolaista. Nordic noirille lajityypilliseen tapaan sarjan tarina nousee ajankohtaisesta yhteiskunnallisesta kysymyksestä, joka Kaikki synnit -televisiosarjassa on sukupuolittunut väkivalta ja seksuaalinen häirintä. Sarjan analyysin teoreettisena viitekehyksenä on 2000-luvun affektiteoria, jossa affektiivisuus ymmärretään kulttuurissa ja yhteiskunnassa syntyneenä.

Kaikki synnit -televisiosarjan musiikki hyödyntää affektiivisuutta keskeisenä katsomiskokemusta ja tarinaa jäsentävänä tekijänä. Sarjan tarinamaailmassa yhteisön affektiivisuus näyttäytyy sidoksina ja katkoksina, jota musiikki ilmentää. Sarjaa tarkastellaan artikkelissa feministisen estetiikan valossa: yksiselitteisen väkivallan toistamisen sijaan sarja pyrkii kohti kerrontaa, jossa tarinan päätepisteenä ei ole kosto vaan sovinto menneisyyden kanssa.

Avainsanat: Kaikki synnit, nordic noir, televisiosarjan musiikki, affekti, seksuaalinen häirintä, feministinen estetiikka

\section{EI \\ Jyrki Korpua \& Juho Longi}

\section{FACE VERSUS HEEL - BATTLE OF GOOD AND EVIL IN AMERICAN TELEVISED PROFESSIONAL WRESTLING}

The article investigates the stereotyped battle of "good" versus "bad" on televised American professional wrestling. Professional wrestling, or "Sports Entertainment" as WWEpromotion calls it, is an extremely popular audiovisual spectacle, which combines elements of sports, martial arts, theatre, and dance performances. It also uses spectacular theatrical reactions and audience participation on competitions, where outcomes are (usually) predetermined.

Demonstrating a structural analysis of the narrative, the article focuses on the construction of a professional wrestling spectacle by doing a case study on a series of matches from WWE (World Wrestling Entertainment), where Shinsuke Nakamura, a stereotyped "good" wrestler (so-called Face) fought against Samoa Joe, a stereotyped "evil" wrestler (so-called Heel).

Keywords: professional wrestling, show wrestling, media spectacle, sports entertainment, face, heel

\section{FACE VASTAAN HEEL - HYVÄN JA PAHAN VASTAKKAIN- ASETTELU YHDYSVALTALAISESSA SHOWPAINISSA}

Artikkeli käsittelee stereotyyppisen "hyvän" ja "pahan" kamppailua yhdysvaltalaisessa televisioidussa showpainissa. Showpaini on yleisöviihdettä, jossa kamppailulajit yhdistyvät teatterimaiseen esiintymiseen käsikirjoitetuissa ja 
ennalta päätetyissä tarinoissa. Showpaini on suureellista spektaakkelia, jossa käytetään liioiteltuja reaktioita.

Tämä artikkeli käsittelee hyvän ja pahan kohtaamista showpainissa yhden erityisen kuvaavan tapausesimerkin kautta, joka on valikoitu yhdysvaltalaisesta WWE-showpainiorganisaatiosta. Tapausesimerkissä "hyvä" (face) eli Shinsuke Nakamura kohtasi "pahan" (heel) eli Samoa Joen sarjassa otteluita, jotka televisioitiin suurelle yleisölle ja joihin liittyi runsaasti oheismateriaalia Internetissä. Artikkelimme tarkastelee, kuinka tämä spektaakkelinen kokonaisuus rakennettiin tarinallisesti näistä elementeistä. Kysymme, miten ja millaisista osista televisioitu showpaininarratiivi rakentuu.

Avainsanat: showpaini, mediaspektaakkeli, urheiluviihde, face, heel.

\section{$\mathbf{y}$}

\section{Noora Kallioniemi \& Sami Hantula}

\section{POLITICAL ENTERTAINMENT PROGRAM FRANK PAPPA SHOW AS A CONTEMPORARY COMMENTATOR ON THE 1990S RECESSION IN FINLAND}

In this article, we study the news parody program Frank Pappa Show as an example of how television programs of the 1990s that combine topicality and entertainment began to use realitybased audiovisual material as part of their programs. The relationship between fact and fiction changed and a new kind of political publicity emerged when the actions of politicians were mocked in a weekly carnivalistic television broadcast. The Frank Pappa Show commented on the upheavals of Finland's recession in the 1990s, such as rising unemployment. The Frank Pappa Show reshaped the field of political entertainment by raising the last fortress of objectivity, news, for entertainment use, and accustomed viewers to interpreting ironic, satirical, and parodic messages.

As the original source for this cultural-historical research, we use episodes of the Frank Pappa Show from 1991 to 1994 , as well as press discussions related to the program. Using these materials, we study how the program contributed to the public debate on politics in the 1990s.

We study the boundaries of the debate, which tells about the media of the time and the culture of public debate. The Frank Pappa Show serves as an example of a new form of television at a time when cinematic expression and the aesthetics of music videos were spreading to television. Accelerated television narration required of its viewers the ability to follow changing narration. The mundane nature of television led to a taste for the spectacle, and the program also critically commented on its own media environment.

Keywords: media history television, entertainment, satire, Frank Pappa

\section{BAILATAAN ANKARASTI! POLIITTINEN VIIHDEOHJELMA FRANK PAPPA SHOW 1990-LUVUN LAMA-AJAN AIKALAISKOMMENTAATTORINA}

Tarkastelemme uutisparodiaohjelma Frank Pappa Show'ta esimerkkinä 1990-luvun alun asiaviihteen ohjelmistosta, jota määrittävät uudenlainen faktan ja fiktion suhde sekä viihteellisen poliittisen julkisuuden syntyminen. Indieyhtiö Broadcasters Oy:n tuottama televisiosarja kommentoi ajantasaisesti lama-ajan murroksia, kuten piteneviä leipäjonoja ja kasvavaa työttömyyttä. Frank Pappa Show uudisti poliittisen viihteen kenttää nostamalla viimeisen asiallisuuden linnakkeen, uutiset, viihteen käytettäväksi ja totutti katsojat tulkitsemaan ironisia, satiirisia ja parodisia viestejä.

Tämän kulttuurihistoriallisen tutkimuksen alkuperäislähteenä käytämme Frank Pappa Show'n jaksoja vuosilta 1991-1994 ja lisäksi ohjelmaan liittyvää lehdistökeskustelua. Näiden aineistojen avulla tarkastelemme kysymystä siitä, miten Frank Pappa Show'n televisuaalinen satiiri osallistui politiikasta käytävään julkiseen keskusteluun 1990-luvulla.

Tarkastelemme keskustelun reunaehtoja, jotka kertovat ajan mediasta ja julkisesta keskustelukulttuurista. Frank Pappa Show toimii esimerkkinä uudesta television muotokielestä aikana, jolloin elokuvallinen ilmaisu ja musiikkivideoiden estetiikka levisivät televisioon. Nopeutunut televisiokerronta vaati katsojilta kykyä seurata muuttuvaa kerrontaa. Television arkipäiväistymi- nen johti spektaakkelimaistumiseen ja ohjelma kommentoi kriittisesti myös omaa mediaympäristöään.

Avainsanat: mediahistoria, televisio, asiaviihde, satiiri, Frank Pappa

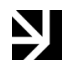

Miisa Rotola-Pukkila \& Pekka
Isotalus

FRIENDSHIP OR ILLUSION? THE APPEARANCE OF PARASOCIAL RELATIONSHIPS IN FOLLOWERS' MESSAGES TO THE SOCIAL MEDIA INFLUENCER

Followers may develop an emotional, affective, and one-sided friendshiplike bond with a social media influencer, also known as a parasocial relationship. Social media creates a good basis for the development of parasocial relationships because followers have an opportunity to peek into influencers' private lives, while the influencers disclose personal issues and address the audience in an acquaintance-like style.

In this article, the formation of parasocial relationships and the elements that foster them are considered. The study aims to investigate an audience's relationship with Finnish social media influencer Mmiisas (Miisa Rotola-Pukkila). The method used was netnography. The data were collected from private messages, which the followers sent to the influencer on Instagram. The influencer Mmiisas also kept a research journal during the three-week research period.

Results revealed that at least some of the followers had a strong parasocial relationship with the influencer. In the private messages, there were many features of imagined friendship that showed a strong one-sided relationship with the influencer. Nearly all of Mmiisas' content is based on self-disclosure. The results showed that highly personal content seems to foster the characteristics of followers' parasocial relationships in their messages.

The article discusses how beneficial a parasocial relationship is for an influencer. For example, Mmiisas seemed to build a strong 
friendship-like bond with her followers by sharing pieces of private information. The followers' reciprocal communication and self-disclosure create the perspective that a parasocial relationship may also be a confidential relationship between an influencer and his or her followers.

Keywords: parasociality, parasocial relationship, social media, publicity, Instagram

\section{YSTÄVYYTTÄ VAI ILLUUSIOTA? PARASOSIAALISEN SUHTEEN NÄKYMINEN SEURAAJIEN VIESTEISSÄ SOSIAALISEN MEDIAN VAIKUTTAJALLE}

Sosiaalisen median vaikuttajien seuraajille voi muodostua affektiivisia ystävyyden kaltaisia tunnesiteitäeli parasosiaalisia suhteita seuraamiansa mediapersoonia kohtaan. Sosiaalisessa mediassa on otolliset lähtökohdat parasosiaalisten tunteiden syntymiselle ja kehittymiselle, kun vaikuttajat päästävät katsojat kurkistamaan elämäänsä kuvien ja videoiden välityksellä, kertovat itsestään henkilökohtaisia asioita seuraajilleen ja puhuttelevat yleisöä tuttavalliseen tyyliin.

Artikkelissa syvennytään parasosiaalisen suhteen syntyyn ja sitä edistäviin tekijöihin. Tutkimuksen kohteena on sosiaalisen median vaikuttaja Mmiisas eli Miisa Rotola-Pukkila. Tutkimus toteutettiin netnografisella tutkimusmenetelmällä, ja parasosiaalisen suhteen ilmenemistä vaikuttajalle tarkasteltiin seuraajien lähettämistä Instagramin yksityisviesteistä. Lisäksi vaikuttaja kirjasi havaintojaan ja ajatuksiaan parasosiaalisesta ilmiöstä kolmen viikon ajan tutkimuspäiväkirjaan.

Tuloksista ilmeni, että ainakin osalla seuraajista saattaa olla hyvinkin vahva parasosiaalinen suhde sosiaalisen median vaikuttajaan. Seuraajien yksityisviesteistä oli havaittavissa monia kuvitellun ystävyyden piirteitä, jotka osoittavat vahvaa yksipuolista tunnesidettä vaikuttajaan. Mmiisas-vaikuttajan lähes kaikki sisältö perustuu itsestäkertomiseen. Tuloksista on nähtävissä, että kaikista henkilökohtaisimmat aiheet edistivät vahvimmin seuraajien parasosiaalisen suhteen ulottuvuuksien ilmenemistä viesteissä.

Tulosten pohjalta artikkelissa myös pohditaan, missä mielessä parasosiaalinen suhde on vaikuttajalle tavoittele- misen arvoista, sillä Mmiisas-vaikuttaja rakentaa tiivistä ja lähes ystävyydenkaltaista suhdetta seuraajiinsa yksityisyytensä kustannuksella. Seuraajien vastavuoroinen viestintä ja avoin itsestäkertominen antavat uudenlaista näkemystä siitä, että parasosiaalinen suhde voi olla kuvitellun ystävyyden lisäksi vastavuoroinen ja vahva luottamussuhde vaikuttajan ja yleisön välillä.

Avainsanat: parasosiaalisuus, parasosiaalinen suhde, sosiaalinen media, julkisuus, Instagram 